Gut, 1979, 20, 55-58

\title{
Jejunal lysozyme activity and the Paneth cell in coeliac disease
}

\author{
M. WARD ${ }^{1}$, A. FERGUSON, AND M. A. EASTWOOD \\ From the University of Edinburgh and Gastrointestinal Unit, Western General Hospital, Edinburgh
}

SUMMARY The jejunal mucosa of patients with coeliac disease contains significantly fewer Paneth cells (PCC) per crypt $(\mathbf{P}<0.001)$ and tissue lysozyme activity (JLA) $\mathbf{P}<0.001)$ when compared with a group of subjects with normal jejunal mucosa. Neither PCC nor JLA return to normal with complete clinical recovery and otherwise complete histological recovery on a gluten free diet. There is a significant linear correlation between JLA and PCC suggesting that the Paneth cell is the principal source of jejunal lysozyme.

The Paneth cell occupies a prominent site at the base of the small intestinal crypt and is a secretory cell discharging its granules in response to pilocarpine (Cordier, 1923). It has been estimated that the adult small intestine contains $2 \times 10^{8}$ cells (Creamer and Pink, 1967) constituting an aggregate gland of similar size to the pancreas (Toner, 1968). Although the function of the cell and secretions remains unknown, the possibilities of dipeptidase digestive activity (Van Genderen and Engel, 1938) and nutritional support of the epithelial cell (Creamer, 1967) have both been proposed. Alternatively, a role in non-specific immunity is suggested by the finding that the cell contains and secretes lysozyme (Peeters and Van Trappen, 1975) and has phagocytic properties (Erlandsen and Chase, 1972).

Little is known of the function and structure of the Paneth cell in disease but it has been reported that, in coeliac disease, reduced numbers of Paneth cells are found in patients who respond incompletely to gluten withdrawal (Creamer and Pink, 1967).

The purpose of the present study, therefore, was to determine whether lysozyme was measurable in homogenates of small bowel biopsies and whether this was quantitatively related to the number of Paneth cells in the tissue. The effect of coeliac disease on these measurements was studied and compared with those in a group of subjects with normal jejunal mucosa.

'Present address: Gastrointestinal Unit, Royal Brisbane Hospital, Brisbane, Queensland 4029, Australia.

Received for publication 6 July 1978

\section{Methods}

\section{PATIENTS}

All subjects studied had undergone jejunal biopsy as part of the routine investigation for gastrointestinal disorders. They were divided into a coeliac group, and a non-coeliac group. The non-coeliac group was selected on the basis of normal jejunal histology and the coeliac group on the basis of typical jejunal histology of the current biopsy or a previous one (Table 1). As shown in this Table the populations used for the two measurements jejunal lysozyme activity (JLA) and Paneth cell counts (PCC) are rather different. This was because in some cases either the sample was too small to provide a homogenate for JLA measurement or the histological sections were not suitable for accurate cell counts. Paired results from the same sample were obtained, however, in 36 cases (11 coeliac; 25 non-coeliac) and these were used to calculate the correlation coefficient. The non-coeliac group used for JLA measurements was composed of 12 subjects with primary alactasia; 32 with symptoms attributed to the irritable bowel syndrome (IBS), and 18 to previous gastric surgery (PGS). The corresponding numbers for the PCC group were eight, primary alactasia; 15, irritable bowel syndrome; and eight, previous gastric surgery.

Of the 26 patients with coeliac disease in whom JLA was measured 17 were taking an apparently gluten-free diet but five showed continued malabsorption. Of these five, two had coexistent pancreatic insufficiency, one a lymphoma, and, in the remaining two, it was thought that occasional 
Table Subjects studied for jejunal lysozyme

\begin{tabular}{llllll}
\hline Subjects & $M / F$ & Mean age $(y r)$ & & \multicolumn{2}{l}{ Villous structure } \\
\cline { 3 - 5 } & & & Normal & Abnormal \\
\hline Coeliac & $26(30)$ & $11 / 15(10 / 20)$ & $41 \cdot 8(44 \cdot 6)$ & $11(12)$ & $15(18)$ \\
Non-coeliac* & $62(31)$ & $23 / 39(10 / 21)$ & $38 \cdot 8(39 \cdot 8)$ & $62(31)$ & - \\
\hline
\end{tabular}

Figures in parentheses refer to subjects used for Paneth cell counts.

*Post-gastric surgery (28), irritable bowel (32), primary alactasia (12).

gluten ingestion was occurring, which accounted for their inadequate recovery.

\section{TECHNIQUE}

Each jejunal biopsy was divided, half being used for histological examination and Paneth cell counts, the other half weighed, then used for disaccharidase and lysozyme assay.

\section{Lysozyme/disaccharidase assay}

The specimen was homogenised in maleate buffer pH 6.3 filtered and the filtrate stored at $-20^{\circ} \mathrm{C}$ until used. Disaccharidase assay was performed by the method of Dahlqvist (1961) and the results expressed as $\mu \mathrm{mol} / \mathrm{mg}$ wet weight of jejunum. Lysozyme assay was performed by the lysoplate method of Osserman (1966) using a purified human lysozyme standard, results being expressed as $\mu \mathrm{g}$ lysozyme activity/mg wet weight of jejunum.

\section{Paneth cell counts}

For each section, the total number of Paneth cells and crypts were counted and the results expressed as Paneth cells per crypt, the mean value being obtained from counts on duplicate sections from each biopsy. Student's $t$ tests were used for statistical comparison between groups.

\section{Results}

The jejunal biopsies of patients with coeliac disease contained significantly fewer Paneth cells $(\mathrm{P}<$ $0.001)$ and reduced lysozyme activity $(P<0.001)$ when compared with the non-coeliac group (Fig. 1). Within the non-coeliac group the subgroups of IBS, PGS, and primary alactasia did not differ significantly from one another with respect to JLA nor PCC.

The numbers of Paneth cells per crypt and the lysozyme activity in the mucosa were not simply a reflection of villus integrity, as the measurements did not differ between the normal villus and the atrophic villus coeliac subgroups. Moreover, there was no significant relationship between JLA and either total or individual disaccharidase activities. The disaccharidase activities of the coeliac group with normal
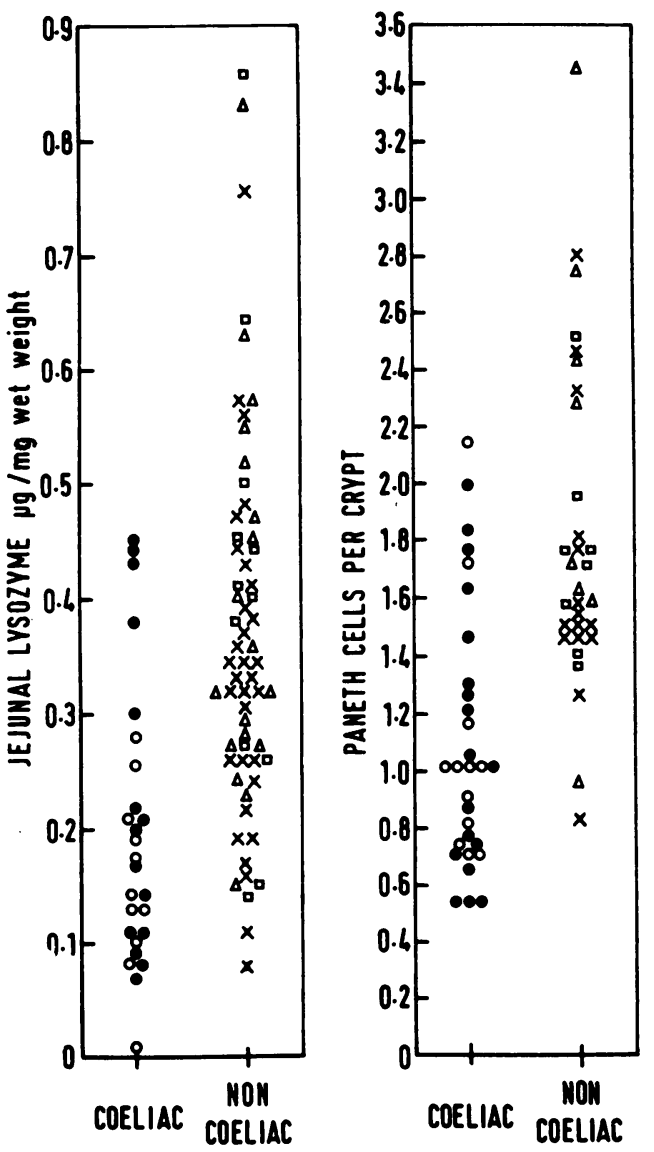

Fig. 1 Jejunal lysozyme activity and Paneth cell counts. Coeliacs: $\bigcirc$ normal villi, 1 atrophic villi. Non-coeliacs: $\times$ irritable bowel syndrome, $\triangle$ postgastric surgery, $\square$ primary alactasia.

mucosa were within the normal range, contrasting with the reduced JLA in this group. Exposure to gluten did not appear to influence results and neither did clinical resistance to a gluten free diet, although the one patient with lymphoma showed a marked reduction in JLA $(0.098 \mu \mathrm{g} / \mathrm{mg})$.

Overall, the pattern of JLA and PCC results were similar, and, where results from the same biopsy 
were available, there was a significant linear relationship between the two measurements $(n=36$, $r=0.33, \mathrm{P}<0.05$ ) (Fig. 2).

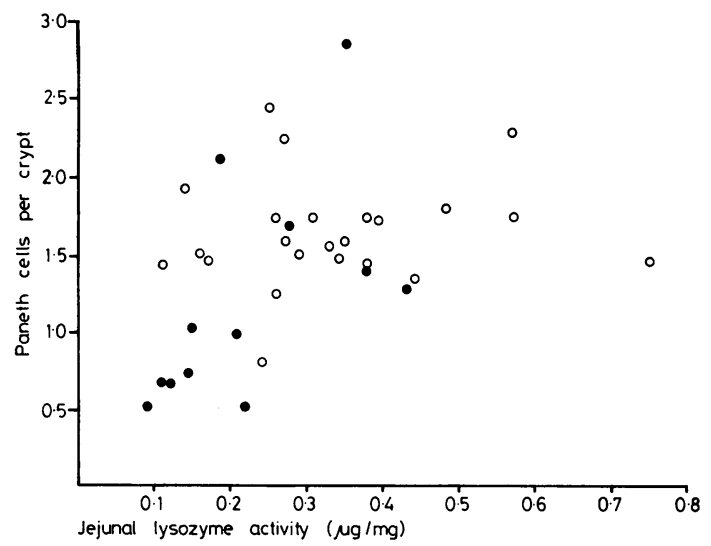

Fig. 2 Relationship between number of Paneth cells per crypt and jejunal lysozyme activity. Coeliac: $\bigcirc$, non-coeliac: 0.

\section{Discussion}

The present study has shown that lysozyme activity is easily measurable in the homogenates of jejunal mucosa used for disaccharidase assay. The linear relationship of tissue lysozyme activity (JLA) with the number of Paneth cells per crypt in the specimen suggests that these cells are the main source of lysozyme. This would be supported by immunocytochemical studies localising lysozyme in the secretion granules of these cells, with only minor contributions from leucocytes (Erlandson et al., 1973; Peeters and Van Trappen, 1975). Also, homogenates of gastric and rectal biopsies which do not contain Paneth cells show only traces of lysozyme activity (Ward, unpublished).

We have confirmed the observation of Creamer (1967) of reduced numbers of Paneth cells in the mucosa of patients with malabsorption and villous atrophy unresponsive to a gluten free diet and have shown a corresponding reduction in JLA. We were surprised, however, to find that there was a similar reduction in Paneth cell counts and JLA in the mucosa of symptom free coeliac patients whose mucosa had returned completely to normal on a gluten free diet.

These findings could be interpreted as indicating a true reduction in the numbers of Paneth cells in the jejunal mucosa of coeliac patients, which might be a marker of, or even the cause of, their sensitivity to gluten. Almost 40 years ago it was proposed that the Paneth cell might produce a dipeptidase (Van Genderen and Engel, 1938) and the possibility that coeliac disease might be due to a peptidase deficiency with inability to digest gluten has also been debated (Douglas and Booth, 1970; Cornell and Townley, 1973). Certainly, the curious species differences in the occurrence of Paneth cells, and, in particular, their absence from the gut of carnivores (Wheeler and Wheeler, 1964) suggests a dietary role.

An alternative and perhaps more likely explanation is that the Paneth cells in coeliac patients more readily discharge their granules. As the cells are distinguished principally by their characteristic granules, discharged cells would be difficult to recognise and count, and the lysozyme activity in the tissue would obviously also be reduced. The discharged Paneth cells could result from either undue sensitivity to neural or chemical stimuli or to a lysosomal membrane instability. This might represent a sensitive indicator of persisting mucosal fragility despite complete villus recovery on gluten withdrawal. The recent report of raised serum lysozyme activity in coeliac patients (Mallas et al., 1976), taken in conjunction with our finding of reduced mucosal lysozyme, is perhaps analogous to the association of raised serum alkaline phosphatase (of intestinal origin) with reduced jejunal alkaline phosphatase, which is also seen in coeliac disease.

The phagocytic activity of the Paneth cell (Erlandsen and Chase, 1972) and the antibacterial properties of lysozyme which these cells secrete (Peeters and Van Trappen, 1975) suggests a role in mucosal defences. This would be supported by the finding of high levels of lysozyme activity in the upper small gut juice in conditions of microbial overgrowth (Kudinova, 1976). The anti-microbial activity of lysozyme is not solely antibacterial, however, as it has been shown to have an antiviral effect separate from its enzymatic action (Ribble and Hook, 1959). It has also been proposed that the secretion of the Paneth cells might be involved in the control of neoplasia and thus account for the low incidence of neoplasms in the small gut (Black and Ogle, 1948). In this context it is also of relevance that lysozyme alters the growth patterns of normal and transformed mammalian cells, perhaps indicating that it plays a part in neoplasia control (Osserman et al., 1973). It is obviously tempting, therefore, to speculate that the deficiency of Paneth cells and lysozyme in the coeliac mucosa may be related to the increased incidence of lymphomata in this condition. This might be caused by either loss of control of an oncogenic virus, or by a direct effect on the cell membrane.

We are grateful to Dr W. Sircus for permission to study patients under his care, and to Mrs D. Smith for disaccharidase assays. 


\section{References}

Black, C. E., and Ogle, R. S. (1948). Influence of local acidification of tissue bordering cancerous growths. Archives of Pathology, 46, 107-118.

Cordier, R. (1923). Contribution a l'étude de la cellule de Ciaccio-Masson et de la cellule de paneth. Comptes Rendus Hebdomadaires de la Société de Biologie, 88, 12271230.

Cornell, H. J., and Townley, R. R. W. (1973). Investigation of possible intestinal peptidase deficiency in coeliac disease. Clinica Chimica Acta, 43, 113-125.

Creamer, B. (1967). Paneth cell function. Lancet, 1, 314-316.

Creamer, B., and Pink, I. J. (1967). Paneth cell deficiency. Lancet, 1, 304-306.

Dahlqvist, A. (1964). Method for assay of intestinal disaccharidases. Analytical Biochemistry, 7, 18-25.

Douglas, A. P., and Booth, C. C. (1970). Digestion of gluten peptides by normal human jejunal mucosa and by mucosa from patients with adult coeliac disease. Clinical Science, 38, 11-25.

Erlandsen, S. L., and Chase, D. G. (1972). Paneth cell function; phagocytosis and intracellular digestion of intestinal microorganisms. Journal of Ultrastructure Research, 41, 296-378.

Erlandsen, S. L., Parsons, J. A., and Taylor, T. D. (1973). Ultrastructural immunocytochemical localization of lysozyme in the Paneth cells of man. Journal of Histochemistry and Cytochemistry, 22, 401-413.

Kudinova, T. I. (1976). Lysozyme as a factor of local protection in the gastrointes tinal tract of patients with chronic disease of the digestive organs (Russian). Antbiotiki, 21, 441-444.

Mallas, E., Terry, J. M., Asquith, P., and Cooke, W. T. (1976). Serum lysozyme in inflammatory bowel and coeliac disease. Journal of Clinical Pathology, 29, 598-600.

Osserman, E. F., Klockars, M., Halper, J., and Fischel, R. E. (1973). Effects of lysozyme on normal and transformed mammalian cells. Nature, 243, 331-335.

Osserman, E. F., and Lawlor, D. P. (1966). Serum and urinary lysoxyme (muramidase) in monocytic and monomyeolocytic leukemia. Journal of Experimental Medicine, 124, 921-952.

Peeters, T., and Van Trappen, G. (1975). The Paneth cell, a source of intestinal lysozyme. Gut, 16, 553-558.

Ribble, J. C., and Hook, E. W. (1959). Inactivation of bacteriophage by lysozyme. (Abstract). Federation Proceedings, 18, 594.

Toner, P. G. (1968). Cytology of intestinal epithelial cells. International Review of Cytology, 24, 233-343.

Van Genderen, H., and Engel, C., (1938). On the distribution of some enzymes in the duodenum and the ileum of the rat. Enzymologia, 5, 71-8C.

Wheeler, E. J., and Wheeler, J. K. (1964). Comparative study of Paneth cell in vertebrates. (Abstract). Anatomical Record, 148, 350. 